Open Access

\title{
Cultural insights of CSI: how do Italian and Iranian firms differ?
}

Rossella Canestrino ${ }^{1 *}$, Angelo Bonfanti ${ }^{2}$ and Leila Oliaee ${ }^{3}$

\author{
* Correspondence: \\ rossella.canestrino@uniparthenope.it \\ ${ }^{1}$ Department of Managerial Studies \\ and Quantitative Methods, \\ Parthenope University, Via Generale \\ Parisi 13, Naples 80132, Italy \\ Full list of author information is \\ available at the end of the article
}

\begin{abstract}
Both scholars and practitioners have paid little attention to the social innovation issue at for-profit firm's level. This is particularly true with reference to the role that culture and cultural diversities may have in shaping firms' orientation toward Corporate Social Innovation (CSI). According to the underlined observation, this paper aims to fill the existing research gap about the topic. Through an inductive approach, an extensive literary review about the cultural drivers of innovation and Corporate Social Responsibility (CSR) has been carried to gain a wide understanding of CSI. Hofstede's cultural model has been, then, used to interpret the cultural insights of CSI in two geographical and psychological distant countries, namely Italy and Iran. This cross-cultural comparison will allow both academics and practitioners to recognize culture as key driver of firms' propensity to adopt social innovative practices.
\end{abstract}

Keywords: Innovation, Corporate social responsibility, Corporate social innovation, Culture, Cultural diversity, Italian and Iranian firms, Hofstede's model

\section{Background}

The concept of social innovation (SI) has been one of the most discussed in the field of innovation for the last years (e.g., Ashta et al. 2014) and even getting stronger in the discussion of social development (Rüede and Lurtz 2012). According to Mulgan (2006), SI refers to innovative activities and services that are motivated by the goal of meeting a social need and that are predominantly developed through organizations whose primary purpose is social. SI refers to ideas, concepts, processes, and outcomes that address social needs in new ways and, if truly successful, fundamentally change social, economic, or other relations (Hansson et al. 2014). For example, the introduction of innovative approaches to help disable people, the emergence of online self-help health groups, the use of distance learning systems to develop knowledge (Maggioni and Del Giudice 2011; Del Giudice et al. 2013), as well the adoption of technology to manage the food problems (Bonfanti et al. 2013) in underdeveloped countries and environmental pollution are all examples of SI practices.

In addition to governments, educational institutions, associations (i.e., fair trade), and user movements (i.e., Wikipedia, Linux), individual entrepreneurs and commercial corporations (Krull 2008; Baccarani and Golinelli, 2013) may also develop SI.

Despite the increasing amount of literature about SI, scholars have paid little attention to the adoption of its practices at corporate level that means to the development of Corporate Social Innovation (CSI) (Tham 2010). The term has been articulated by

(c) 2015 Canestrino et al. Open Access This article is distributed under the terms of the Creative Commons Attribution 4.0 International License (http://creativecommons.org/licenses/by/4.0/), which permits unrestricted use, distribution, and reproduction in any medium, provided you give appropriate credit to the original author(s) and the source, provide a link to the Creative Commons license, and indicate if changes were made. 
Rosabeth Moss Kanter (1999) for the first time. The author argued that firms should use social issues as a learning laboratory for identifying unmet needs and developing solutions. According to the given perspective, CSI may be defined as a way of finding new products and services that meet not only the functional needs of consumers but also their wider aspirations as citizens (Webb 2007).

CSI is hitherto under-explored research area because of problems about both its understanding and its management. On the one hand, understanding CSI requires examining the existing overlapping between the theoretical backgrounds usually used to explain these concepts: firms' innovation theories, on one side, and corporate social responsibility (CSR), on the other one. Adopting a socially responsible behavior means that firms' innovative actions are oriented toward socially valuable goals, thus CSI belongs to both SI and CSR framework. In other words, managing CSI demands to evaluate both firms' innovation activities and their social responsibility in an integrated manner. Additionally, if firms' innovation may be considered the output of a knowledge management process (Nonaka and Takeuchi 1995; Galunic and Rodan, 1998; Apanasovich 2014), CSI may be interpreted as a way to manage firms' knowledge in order to get not only profits but also social goals. Its effectiveness depends on the firms' ability to manage both knowledge for innovation and their propensity to achieve social benefits.

As widely highlighted in management literature, culture affects both firms' innovativeness and CSR (e.g., Kaasa and Vadi 2010). Since values and beliefs differently shape firms' innovative behavior, culture may enable the emergence of CSI. However, firms' involvement in social innovative practices may differ according to the cultural values that prevail in a given context. Taking into account these considerations, we aim to investigate the role of culture and cultural diversities, in defining CSI.

The paper proceeds as follows. First, we highlight the linkage between culture, innovation, and CSR by discussing that culture plays in defining firms' innovative behavior as well as firms' propensity to devote its actions to social aims. Next, we discuss the concept of CSI and the use Hofstede's cultural model to interpret the cultural insights of CSI in two geographical and psychological different countries, namely Italy and Iran. Conclusions, research limits and the undertaken research method are proposed at the end.

Firm's innovation attitude and social responsible orientation: how does culture matter? Culture plays a very important role in both the innovation field and the ground of social responsibility. Focusing on innovation, many authors examined the linkage between national culture (Hofstede 1980; Kaasa and Vadi 2010; Petrakis and Pantelis 2014) and firms' propensity to innovate, by mainly concentrating on the initiation stage of the process that means on the creativity stage (e.g., Parjanen 2012). More frequently, scholars investigate the role of Hofstede's cultural dimensions (power distance, individualism versus collectivism, masculinity versus femininity, uncertainty avoidance, and long-term orientation as the fifth dimension added to the original model) on national innovation rates (e.g., Kaasa and Vadi 2010; Taylor and Wilson 2012). The analysis of these studies allows us to point out the two following considerations: (a) each cultural dimension differently affects the different stages of an innovation process (innovation 
creation and innovation transfer and diffusion), by shaping the way new knowledge is created and then diffused, and (b) a general agreement seems to prevail in literature about the positive relationship between individualism, masculinity, power distance, long-term orientation, and firms' propensity to create innovation.

The linkage between culture and CSR is widely discussed in the business ethics field (e.g. Husted 2001; Robertson 2002). Within the referred research arena, many scholars recognize that what is ethically right or wrong is culturally affected. But, what does culture mean?

Culture may be considered as the set of driving rules and core beliefs that develop in a society over time (Schein 1985) and these drive both individuals and firms' choices. In line with this notion, and taking into account the mainstream literature about the topic, culture and cultural diversities may affect the following: (a) the assumption about what may be considered moral or not in different countries (Husted and Allen 2008; Moores 2003); (b) firms' propensity to adopt a CSR behavior; and (c) firms' practicing CSR (explicit vs implicit). Research in CSR has identified remarkable differences between companies from different countries (Canestrino et al. 2012). For example, Matten and Moon (2008) pointed out that US corporations usually explicitly commit to CSR, whereas European business responsibility tends to be more implicit. In coherence with our literary examination, we agree with the following three aspects: (a) individualism positively relates to firms' propensity to adhere and to adopt "explicit" social responsible practices. The higher the individualism index is, the more corporates' policies, programs, and strategy could devote to the stakeholders interests. The lower individualism is, the higher is the adoption of "implicit" responsible practices; (b) masculinity and power distance negatively relate to firms' propensity to adhere and to adopt social responsible practices. The higher masculinity (or power distance) index is, the less corporates' policies, programs, and strategy devote to the stakeholders interests; and (c) uncertainty avoidance positively relates to firms' propensity to adhere and to adopt social responsible practices. The higher the uncertainty avoidance is, the more corporates' policies, programs, and strategy could devote to the stakeholders interests.

Crossing the main findings of our theoretical investigation, we examine CSI in Italy and Iran and highlight cultural differences for CSI between these two countries in the next sections.

\section{Understanding CSI: a comparison between Italy and Iran}

Putting together the examined literary contributions, we define CSI as the introduction of a new way, method, or system (innovation) to meet collective needs in a social responsible manner. Our definition enlarges the previous notions of CSI by introducing the need for a socially responsible orientation not only referring to the aimed goals but also with respect to the way the goals (societal needs) are satisfied. Therefore, CSI requires both a high firm's propensity to innovate and a high CSR orientation. With reference to both these aspects, Italy and Iran seem to contrast.

In the field of innovative activities, the Global Innovation Index (GII) provides relevant data to compare the countries' innovation dynamics at the global level. It ranks the innovation performance of 143 countries and economies around the world, based on 81 indicators. 
According the Global Innovation Index (2014), Italy scores for 45.65 and ranks for 31 within the global countries' classification. Conversely, Iran locates at 120th position at global level (Table 1).

Italy and Iran significantly differ in their innovative performance at global level, confirming an innovative divide between the two countries. The innovation divide between the two countries reduces with reference to the income group classification. This suggests us to consider the national income as a moderating factor in the influence that cultural diversities have on local innovative behavior.

A national index does not exist for the evaluation of CSR. The most suitable tool to compare firms' social orientation in a wider context is, therefore, the Global Entrepreneurship Monitor (GEM) that documents the prevalence of social entrepreneurship (SE) in a given population. In this regard, the management literature does not provide uniform definition or understanding of SE (e.g., Bacq and Janssen 2011). For example, SE includes activities of individuals and groups (social entrepreneurs) who identify gaps in the social system as an opportunity to serve groups who are marginalized in different ways and aims to address these needs in entrepreneurial ways (Hansson et al. 2014). In this sense, SE and SI are interrelated but not interchangeable concepts. GEM uses a broad definition of SE, the last one interpreted as entrepreneurial activity with a social orientation and that involves an organization of individual (Mair and Martí 2006; Zahra et al. 2009). Social activity includes the following categories of players: (1) traditional NGO (explicit social purpose-not self-sustaining-not innovative); (2) not for profit SE (explicit social purpose-not self-sustaining-innovative); (3) hybrid SE (overlapping social and economic purposes-self-sustaining); and (4) for profit SE (explicit economic purpose-socially committed self-sustaining).

As showed in Table 2, both Italy and Iran rates for strictly defined SE are below the average for-respectively-Western Europe and Middle and North Africa (MENA). But while Italy is about $30 \%$ far from its average, Iran diverges only for about $8 \%$. This suggests that Iran performs better than Italy within its own geographical area. The underlined gap reduces when we refer to the broadly defined SE (that includes NGOs and for profit SE). In the Table 2, while "strictly defined" includes only not-for-profit SE, and hybrid SE (both economic and socially oriented) as parts of the spectrum, "broadly defined" includes all the five categories.

Obviously, the data need to be justified within each national context. This is because social enterprises can take numerous forms, are engaged in multiple spheres of activity, and because legal structures vary from country to country. For example, in Italy, social enterprises are constrained by a non-distribution clause-that is, all income has to be reinvested in the enterprise. In Iran, the Government's absolute monopoly in the economy is one of the most important factors that prevent the provision of necessary requirements for the implementation of social entrepreneurship. Legally, most of the

Table 1 Global innovation index-Italy versus Iran

\begin{tabular}{lllllll}
\hline Country & Score (0-100) & Rank & Income & Rank & Region & Rank \\
\hline Italy & 45.65 & 31 & High Income & 30 & Europe & 20 \\
Iran & 26.14 & 120 & Upper middle income & 35 & Central and Southern Asia & 6 \\
\hline
\end{tabular}

Source: our adaptation by Global Innovation Report 2014 
Table 2 Rates of social entrepreneurship by types and countries

\begin{tabular}{|c|c|c|c|c|c|c|c|}
\hline Country & $\begin{array}{l}\text { Traditional } \\
\text { NGO }\end{array}$ & $\begin{array}{l}\text { Not-for- } \\
\text { profit SE }\end{array}$ & $\begin{array}{l}\text { Economically } \\
\text { oriented hybrid SE }\end{array}$ & $\begin{array}{l}\text { Socially } \\
\text { oriented } \\
\text { hybrid SE }\end{array}$ & $\begin{array}{l}\text { For-profit } \\
\text { SE }\end{array}$ & $\begin{array}{l}\text { Strictly } \\
\text { defined SE }\end{array}$ & $\begin{array}{l}\text { Broadly } \\
\text { defined SE }\end{array}$ \\
\hline Italy & 0.27 & 0.55 & 1,32 & 0.45 & 0.69 & 2.32 & 3.28 \\
\hline $\begin{array}{l}\text { Average for } \\
\text { Western Europe }\end{array}$ & 0.27 & 1.11 & 1,01 & 1.19 & 1.01 & 3.31 & 4.58 \\
\hline $\begin{array}{l}\text { Percentage on } \\
\text { the average }\end{array}$ & 100 & 49.5 & 130 & 37.8 & 68 & 70 & 71.6 \\
\hline Iran & 0.06 & 0.45 & 1,25 & 0.17 & 0.62 & 1.87 & 2.55 \\
\hline Average for MENA & 0.14 & 0.76 & 0,76 & 0.51 & 0.80 & 2.03 & 2.97 \\
\hline $\begin{array}{l}\text { Percentage on } \\
\text { the average }\end{array}$ & 43 & 59.2 & 164 & 33.3 & 77.5 & 92.1 & 85.8 \\
\hline
\end{tabular}

Source: our adaptation by Global Entrepreneurship Monitor (2009) Adult Population Survey

Bold data symbolizes the average for Western Europe and Iran

rules on social efforts are obsolete or not up-to-date. Politically, social issues are majorly viewed from the political and security points of view. This could hamper the effect of non-governmental organizations and pose problems for the engagement of SE (Razavi et al. 2014).

SE may also cover a wide range of organizations from cooperatives to public service providers, from community/voluntary associations to "work insertion" organizations, and from companies limited by guarantee, thus posing huge attention in the interpretation of the available data. According to this, using the cultural lens to interpret SE allows us to contextualize data, as well as to give a punctual picture of SE that prevail in a given country.

Interpreting the diversities in CSI between Italy and Iran: a cultural perspective

A first cultural comparison between Italy and Iran bases on the diversities in Hofstede's rankings, as it is showed in the Table 3. The scale for each dimension runs from 0 to 100 with 50 as a midlevel. The rule of thumb is that if a score is under 50 , the culture scores relatively low on that scale, and if any score is over 50, the culture scores high on that scale. In the case of IDV-the low side (under 50), is considered "Collectivist" and above 50 considered "Individualist". A country with a score of 43 would be collectivist but less collectivist than someone with 28 who is moving down toward the 0 mark (Hofstede et al. 2010).

The cross-cultural comparison between Italy and Iran shows that significant diversities exist between the two countries with reference to individualism, masculinity, and long-term orientation. In particular, at a score of 76, Italy is an individualistic

Table 3 Hofstede's model: a comparison between Italy and Iran

\begin{tabular}{lll}
\hline Cultural dimensions & Italy & Iran \\
\hline Individualism (IND) & 76 & 41 \\
Power distance (PD) & 50 & 58 \\
Masculinity (MAS) & 70 & 43 \\
Uncertainty avoidance (UA) & 75 & 59 \\
Long-term orientation (LO) & 61 & 14 \\
\hline
\end{tabular}

Source: our adaptation by Hofstede et al. (2010) 
and "me"-centered culture. Conversely, Iran, with a score of 41, is considered a collectivistic society. This is manifested in a close long-term commitment to the member "group," be that a family, extended family, or extended relationships. At 70, Italy is a masculine society-highly successful-oriented, and driven. Children are taught from an early age that competition is good and to be a winner is important in one's life. As the working environment is the place where every Italian can reach his/her success, competition among colleagues for making a career can be very strong. Iran scores 43 on this dimension and is thus considered a relatively feminine society. In feminine countries, the focus is on "working in order to live," managers strive for consensus; people value equality, solidarity, and quality in their working lives. Conflicts are resolved by compromise and negotiation. Incentives such as free time and flexibility are favored. Femininity culturally justifies the arising of a more social entrepreneurial orientation, as it has been discussed above.

The mentioned differences could justify the diversities in both the propensity to innovate and the orientation to social responsible practices that characterize the selected countries. It does not mean that knowing the cultural dimensions that characterize a given context allows us to predict local CSR, firms' innovative behavior, and lastly, CSI. There is no quick fix to understand CSI. But the cultural dimensions let us to predict a little better what is likely to happen. And they become more useful as we go from the specific case to the trend, average, or expectation. Since IND positively relates to firms' propensity to innovate, as well as to their attitude to adopt "explicit" social responsible practices, one, for example, would expect that CSI arises in individualistic context more easily than in collectivistic ones or that feminine societies (like Iran) devote to social aims more than masculine ones (like Italy), thus affecting the way firms develop their own initiatives.

From a cultural perspective, for example, Iran shows high levels of power distance, collectivism, femininity and uncertainty avoidance, and low levels of long-term orientation. As data display, Iran characterizes also for low levels of innovation and high levels of social entrepreneurship. In addition, empirical evidences reveal the involvement of both firms and NGO in social-oriented activities, which means in SE. Because of the high collectivism, the group's interest prevails over the individual one at societal level; femininity plays, therefore, a very important role in fostering local solidarity.

Central to the understanding of Iranian SE is also the strong influence of Islam on all aspects of socio-economic life. In Arabic countries, Islam is much more than a religion; it is a way of life, and in many countries, it still has a greater importance than the official law. That is the Islamic moral law, even if not applied by government, still influences people's way of life (Cone 2003).

According to the taqwā paradigm (Dusuki 2008), each individual is claimed to make any deliberate effort to achieve the objectives of Shariah in the ways prescribed by Shari'ah itself. As a consequence, people become voluntarily committed to reach the central goals of human welfare or falah. Furthermore, it plays a unifying role, binding the community together and building the ground for equality, solidarity, and freedom.

Unfortunately, in spite of the underlined considerations, we cannot say anything else about the existing linkage between culture and CSR mainly because of the established relationship between and among the different cultural dimensions as well as between each of them and firms' behavior. 


\section{Results and Discussion}

As already underlined, we have supported the idea that CSI is affected by culture. Since no CSI rankings exist at global level, the GII and GEM ranks have been used to picture the differences between Italy and Iran, as regards to their innovative and social responsible orientation.

Italy performs better than Iran in innovation, but compared to Italy, Iran shows a higher level of SE, within the MENA. Without neglecting the relevance that many other dimensions-economical, political, and cultural environments (Razavi et al. 2014) - have on the development of firms' social and innovative attitude, the mentioned diversities have been examined in the field of cultural studies. According to Hofstede's model, Iran and Italy significantly differ in the following cultural dimensions: (a) individualism: relatively high for Italy and low for Iran and (b) masculinity: relatively high for Italy and low for Iran.

The underlined cultural divide may be-even partially-responsible for firms' attitude toward innovation, SE, and the adoption of CSI, at least. Obviously, there is no quick fix to understand CSI. But the cultural dimensions let us to predict a little better what is likely to happen. Since individualism positively relates to firms' propensity to innovate, as well as to their attitude to adopt "explicit" social responsible practices, one, for example, could expect that CSI arises in individualistic context more easily than in collectivistic ones. Similar considerations could be developed referring to femininity, since feminine societies (like Iran) devote to social aims more than masculine ones (like Italy). Depending on the above, individualistic and feminine contexts would provide the best background for the emergence of CSI.

Despite this, we cannot say anything else, mainly because the relationship that establish between and among the different cultural dimensions, as well as between each of them and firms' propensity to innovate and to devote to social practices.

\section{Conclusions}

This paper provides new insights in the field of CSI by adopting a cultural perspective. The concept of CSI has been examined taking into account the two literary fields to which it belongs to, namely innovation and CSR. Within the reviewed literature, scholars agree on the existing linkage between firms' innovative behaviour and culture on one hand, as well as between the adoption of social responsible practices and the values that prevail in a given context, on the other hand. In spite of our research results, however, many challenges also derive from the effect that cultural norms have on the definition of SE and CSI. Cross-country comparisons of SE and CSI often become difficult "because everyone speaks from their own regionally defined version of the concepts" (Kerlin 2009); in developing countries, every economic activity seems to have a social component, while in other countries like the USA, social and business enterprises are generally seen as different kinds of organizations.

Additionally, the driving forces behind social innovations are manifold. Companies and organizations from all industries (Palacios-Marqués et al. 2015; Trequattrini et al. 2015; Soto-Acosta et al. 2010, 2015; Meroño-Cerdan and Soto-Acosta 2005) and from different cultural contexts may engage social innovative practices for several reasons. Their behavior may be affected by many factors as well as culture-notably national 
wealth, history, personalities, and even coincidences. The above considerations, therefore, mirror the main limits of our paper.

Our research represents only a little step in the exploration of a wide and often misunderstood concept. We recognize that many questions are still unanswered. What does it happen, for example, when high levels of individualism and masculinity cross? How does power distance-or even uncertainty avoidance-influence CSI? Despite its inner limits, our paper contributes to the literature improving about CSI by developing a more comprehensive knowledge and culturally based perspective.

\section{Methods}

Our paper is based on an inductive approach. An extensive literary review about the cultural drivers that lie under the adoption of innovation and corporate social responsibility has been carried to gain a wide understanding of CSI. The examined literary contributions have been then crossed with the available data about the country innovation dynamics, on one side, and the rates of social entrepreneurship by countires, on the other side, in order to compare firms'attitude toward SI in two different countires, namely, Italy and Iran. Hofstede'cultural model has been, finally, used to interpet the cultural insights of CSI in the two selected countries.

Competing interests

The authors declare that they have no competing interests.

\section{Authors' contributions}

CR; BA; and OL, carried an investigation about the cultural drivers that lie upon the adoption of CSI, comparing firms' propensity to adopt innovation and to adhere to social responsible practices in two geographical and cultural distant countries, namely Italy and Iran. BA explored the insights of firms' innovation attitude and social responsible orientation; OL provided the picture to understand Iranian firms' behavior; CR developed the cultural interpretation for the emerging differences between Italian and Iranian firms. All the three authors conceived the study, partecipated in its design and drafted the manuscript. All the authors read and approved the final manuscript.

\section{Author details}

${ }^{1}$ Department of Managerial Studies and Quantitative Methods, Parthenope University, Via Generale Parisi 13, Naples 80132, Italy. ²Department of Business Administration, University of Verona, Via dell'Artigliere 19, Verona 37129, Italy. ${ }^{3}$ Department of Human Resource, Azad University - Mashad branch, Faculty of Management, 75, Bozorgmehr 5h st., Sajjad blv., Mashad 9186753717, Iran.

Received: 14 October 2015 Accepted: 10 November 2015

Published online: 25 November 2015

\section{References}

Apanasovich, N. (2014). Modes of innovation: a grounded meta-analysis. J Knowl Econ, 12, 1-18.

Ashta, A., Couchoro, M., \& Musa, A. S. M. (2014). Dialectic evolution through the social innovation process: from microcredit to microfinance. J Innov Entrep, 3(4), 1-23.

Baccarani C., Golinelli G.M. (2013) "Per una rivisitazione delle relazioni tra impresa e territorio", Sinergie, n. 84, pp. VII-XIII.

Bacq, S., \& Janssen, F. (2011). The multiple faces of social entrepreneurship: a review of definitional issues based on geographical and thematic criteria. Entrep Reg Dev, 23(5-6), 373-403.

Bonfanti, A., Brunetti, F., \& Castellani, P. (2013). The last minute market model: an innovative service of efficient assortment management in a sustainability perspective. Sinergie, 91, 173-192.

Canestrino, R., Magliocca, P., \& Nocilla, G. (2012). Cross-border knowledge transfer in MNCs: the role of international executives in managing cultural diversities. In AAW political change, cultural dynamics and competitiveness of firms (pp. 86-114). Enzo Albano Editore: Napoli.

Cone, M. H. (2003). Corporate citizenship. The role of commercial organizations in an Islamic society. J Corp Citiz, 9, 49-66.

Del Giudice, M., Della Peruta, M. R., \& Maggioni, V. (2013). Collective knowledge and organizational routines within academic communities of practice: an empirical research on science-entrepreneurs. J Knowl Econ, 4(3), $260-278$.

Dusuki, A. W. (2008). Why does Islam say about corporate social responsibility. Rev Islam Econ, 12(1), 5-28.

Galunic, C., \& Rodan, S. (1998). Resource re-combinations in the firm: knowledge structures and the potential for Schumpeterian innovation. Strateg Manag J, 19(12), 1193-201.

Global Innovation Index. (2014). The human factor in innovation, second printing. Fontainebleau, Ithaca, and Geneva: Cornell University, INSEAD, and WIPO.

Hansson, F., Norn, M. T., \& Vad, T. B. (2014). Modernize the public sector through innovation? A challenge for the role of applied social science and evaluation. Evaluation, 20(2), 244-260. 
Hofstede, G. (1980). Culture's consequences: international differences in work-related values. Los Angeles: Sage Publication. Hofstede, G., Hofstede, G. J., \& Minkov, M. (2010). Cultures and organizations: software of the mind. USA: McGraw-Hill. Husted, B. W., \& Allen, D. B. (2008). Toward a model of cross-cultural business ethics: the impact of individualism and collectivism on the ethical decision-making process. J Bus Ethics, 82(2), 293-305.

Husted, B. W. (2001). The impact of individualism and collectivism on the ethical decision-making by individuals in organizations. Mexico: Instituto Tecnologico y de Estudios Superiores de Monterrey and Instituto de Empresa.

Kaasa, A., \& Vadi, M. (2010). How does culture contribute to innovation? Evidence from European countries. Econ Innov N Technol, 19(7), 583-604.

Kanter, R. M. (1999). From spare change to real change: the social sector as beta site for business innovation. Harv Bus Rev, 77, 122-133.

Kerlin, J. A. (Ed.). (2009). Social enterprise: a global comparison. New England: University Press of New England.

Krull, P. (2008). The emerging field of social innovation through corporate social responsibility - four tendencies, 4th EABIS conference. UK: Cranfield University.

Maggioni, V., \& Del Giudice, M. (2011). Relazioni sistemiche tra imprenditorialità interna e gemmazione d'impresa: una ricerca empirica Sulla natura cognitiva Delle nuove imprese. Sinergie, 71, 171-197.

Mair, J., \& Martí, I. (2006). Social entrepreneurship research: a source of explanation, prediction, and delight. J World Bus, $41(1), 36-44$.

Matten, D., \& Moon, J. (2008). "Implicit" and "explicit" CSR: a conceptual framework for a comparative understanding of corporate social responsibility. Acad Manage Rev, 33(2), 404-424.

Meroño-Cerdan, A. L., \& Soto-Acosta, P. (2005). Examining e-business impact on firm performance through website analysis. Int J Electron Bus, 3(6), 583-598.

Moores, T. T. (2003). The effect of national culture and economic wealth on global software piracy rates. Commun ACM, 46(9), 207-215.

Mulgan, G. (2006). The process of social innovation, technology, governance, globalization. MIT Press, 1(2), 145-162.

Nonaka, I., \& Takeuchi, H. (1995). The knowledge-creating company. Oxford: Oxford University Press.

Palacios-Marqués, D., Soto-Acosta, P., \& Merigó, J. M. (2015). Analyzing the effects of technological, organizational and competition factors on web knowledge exchange in SMEs. Telematics Inform, 32(1), 23-32.

Parjanen, S. (2012). Experiencing creativity in the organization: from individual creativity to collective creativity. Interdisciplinary J Inf Knowl Manag, 7, 109-128.

Petrakis, P. E., \& Pantelis, C. K. (2014). Medium term effects of culture, transactions and institutions on opportunity entrepreneurship. J Innov Entrep, 3(11), 1-22.

Razavi, S. M., Asadi, M., Esfandabadi, H. M., \& Ekbatani, H. (2014). Barriers to social entrepreneurship in Iran: an application of grounded theory. J Entrep Organ Manag, 3(2), 2-5.

Robertson, D. C. (2002). Business ethics across cultures. In M. J. Gannon \& K. L. Newman (Eds.), The handbook of crosscultural management. Oxford: Blakwell.

Rüede, D., \& Lurtz, K. (2012). Mapping the various meanings of social innovation: towards a differentiated understanding of an emerging concept. EBS Bus Sch Res Pap Ser, 12(3), 1-51.

Schein, E. H. (1985). Defining organizational culture. Class Organ Theory, 3, 490-502.

Soto-Acosta, P., Casado-Lumbreras, C., \& Cabezas-Isla, F. (2010). Shaping human capital in software development teams: the case of mentoring enabled by semantics. IET Softw, 4(6), 445-452.

Soto-Acosta, P, Popa, S \& Palacios-Marqués, D (2015). E-business, organizational innovation and firm performance in manufacturing SMEs: an empirical study in Spain. Technological and Economic Development of Economy, http://dx.doi.org/10.3846/20294913.2015.1074126

Taylor, M. Z., \& Wilson, S. (2012). Does culture still matter? The effects of individualism on national innovation rates. J Bus Venturing, 27(2), 234-247.

Tham, J. (2010). Corporate social innovation. Soc Space, 1, 48-56.

Trequattrini, R., Lombardi, R., \& Battista, M. (2015). Network analysis and football team performance: a first application. Team Perfor Manag, 21(1/2), 85-110.

Webb, T (2007). Strategy \& management: Unilever's CEO: social innovation and sustainability the only game in town. Ethical Corporation, 5.

Zahra, S., Gedajlovic, E., Neubaum, D., \& Schulman, J. (2009). A typology of social entrepreneurs: motives, search processes and ethical challenges. J Bus Venturing, 24(5), 519-532.

\section{Submit your manuscript to a SpringerOpen ${ }^{\circ}$ journal and benefit from:}

- Convenient online submission

- Rigorous peer review

- Immediate publication on acceptance

- Open access: articles freely available online

- High visibility within the field

- Retaining the copyright to your article

Submit your next manuscript at $>$ springeropen.com 